\title{
ANALISIS HASIL MENGGAMBAR RAGAM HIAS MELAYU DITINJAU DARI PRINSIP-PRINSIP SENI RUPA KARYA SISWA DI SMP KARTIKA I-1 MEDAN
}

\author{
$\operatorname{Sarinah}^{1^{*}}, \mathbf{A z m i}^{2^{*}}$ \\ Program Studi Pendidikan Seni Rupa Jurusan Seni Rupa Fakultas Bahasa dan Seni \\ Universitas Negeri Medan \\ Jl. Willem Iskandar Pasar V Medan Estate, Kec, Percut Sei Tuan, Kab. Deli Serdang, Kode Pos 20371 \\ Sumatera Utara. Indonesia \\ Email: sarinahp9@gmail.com
}

\begin{abstract}
Abstrak
Penelitian ini bertujuan untuk mengetahui kemampuan siswadalam menerapkan prinsip-prinsip seni rupa. Pembatasan masalah dalam penelitian ini, kurangnya kemampuan Siswa dalam menggambar Ragam Hias yang meliputi: keseimbangan, kesatuan, irama, harmoni dan repetisi pengulangan bentuk yang masih rendah. Penelitian ini bermanfaat bagi banyak orang termasuk menambah pengetahuan menyangkut karya ilmiah. Adapun Populasi dalam penelitian ini yaitu seluruh hasil karya gambar Ragam Hias Melayu siswa kelas VII SMP Kartika I-1 Medan Petisah. Sampel diambil menggunakan teknik total sampling yaitu keseluruhan populasi dijadikan sampel. Penelitian ini menggunakan metode deskriptif kualitatif dengan mengetahui bagaimana hasil karya gambar Ragam Hias siswa SMP Kartika I-1 Medan Petisah, setelah itu mendeskripsikan gambar yang diteliti dan dinilai, ditinjau dari prinsip-prinsip seni rupa yang telah ditentukan.Secara keseluruhan karya yang dihasilkan ditinjau dari prinsip-prinsip seni rupa yaitu keseimbangan, kesatuan, irama, harmoni dan repetisi memiliki kualitas yang cukup dengan nilai rata-rata $=71,6$. Nilai tertinggi diperoleh pada prinsip repetisi yaitu 72,4 dengan kategori cukup, nilai terendah diperoleh pada prinsip irama yaitu 67 dengan kategori kurang. Secara umum, nilai rata-rata yang berdasarkan kelima prinsip-prinsip seni rupa sebagai berikut: prinsip keseimbangan $=72,2$, prinsip kesatuan $=72,2$, prinsip irama $=67$, prinsip harmoni $=$ 70,4 dan prinsip repetisi $=72,4$.
\end{abstract}

Kata Kunci: menggambar, ragam hias, prinsip seni.

\begin{abstract}
This research aims to determine the ability of students of junior in applying the principles of arts. The limitation of the problem in this research is the lack of students' ability to draw decoration, the which include: balance, unity, rhythm, harmony and repetition of forms that are still low This research is useful for many people, including as an enhancer of knowledge scientific work. The population in this research is all the drawings of Melayu Ornamental. Samples were taken using total sampling technique, namely the entire population sampled. This research uses a qualitative descriptive method by knowing how the drawings of Ornamental Variety of Grade VII students of SMP Kartika I-1 Medan Petisah, then describing the images studied and assessed, in terms of the principles of art that have been determined.Overall the work produced is viewed from the principles of art, namely balance, unity, rhythm, harmony and repetition that have sufficient quality with an average value $=71.6$. The highest value obtained in the repetition principle is 72.4 with sufficient categories, the lowest value obtained on the principle of rhythm which is 67 with less categories. In general, the average value based on the five art principles is as follows: the principle of balance $=72.2$, the principle of unity $=$ 72.2 , the principle of rhythm $=67$, the principle of harmony $=70.4$ and the principle of repetition $=$ 72.4 .
\end{abstract}

Keywords: analysis, images, illustration, technique, shading.

\section{PENDAHULUAN}

Pendidikan adalah suatu proses untuk mempengaruhi peserta didik supaya mampu menyesuaikan diri sebaik mungkin dengan lingkungannya. Pada dasarnya pertumbuhan dan perkembangan peserta didik bergantung pada dua unsur yang saling mempengaruhi. Pertama, potensi bakat yang dimiliki oleh peserta didik sejak lahir.Kedua, potensi bakat anak yang dipengaruhi oleh lingkungan sehingga bakat itu timbul dan berkembang. Pendidikan salah 
satu alternatif untuk membangun generasi penerus bangsa yang dapat memanfaatkan Sumber Daya Alam yang tersedia. Begitu pula pendidikan yang baik diharapkan dapat mengantisipasi pengaruh budaya luar. Selanjutnya, pendidikan juga merupakan wujud pertahanan sebuah negara terhadap dampak globalisasi yang terjadi saat ini.

Sekolah Menengah Pertama adalah tahapan belajar dimana siswa mengalami peralihan dari Sekolah Dasar menuju Sekolah Menengah Pertama. Maka dari itu siswa SMP masih terlalu banyak bermain dari pada belajar yang serius.

Pada Kurikulum pendidikan, memuat isi dan materi pembelajan. Sekolah SMP Kartika I-1 Medan menerapkan Kurikulum 2013 pada kelas VII, dengan 1 kali pertemuan dalam seminggu. Pada SMP Kartika I-1 Medan terdapat mata pelajaran Seni Budaya, di dalamnya terdapat materi tentang menggambar Ragam Hias. Pada dasarnya pengetahuan siswa tentang Seni Rupa masih dapat dikatakan umum. Hanya saja pengetahuan siswa dalam memahami Ragam Hias masih sangat kurang.

Selain itu, kurangnya pengetahuan dan wawasan siswa tentang Ragam Hias menjadikan karya siswa tidak berkembang. Karena pengetahuan dalam proses menggambar penting diketahui dan akan mempengaruhi karya gambar siswa. Perlu adanya pemahaman karena dalam menggambar Ragam Hias ada beberapa jenis Ragam Hias yang berbeda harus diketahui dan prinsip seni rupa dalam menggambar Ragam Hias.Oleh karena itu, ketika siswa tidak paham mengenai menggambar Ragam Hias maka siswa tidak semangat dalam menggambar Ragam Hias, sehingga karya mereka tidak maksimal.

Hal terpenting lainnya selain keaktifan siswa dalam mencari sumber materi ialah peran guru dalam membimbing dan memberikan informasi sebaikbaiknya dalam mengajar seni budaya.Dari segi teori guru sebaiknya tidak hanya mengajarkan teori berupa materi yang hanya terdapat didalam buku paket saja, tetapi harus mencari bahan ajar yang lebih mendetail pada pelajaran yang diajarkan.Pada pembelajaran praktikum guru harus membimbing siswa dari awal hingga mengerti teknik-teknik dalam menggambar.

Setelah melakukan peninjauan, ternyata masih banyak siswa yang kurang mampu menggambar Ragam Hias, bahkan hasil menggambarnya jauh dari harapan.Mereka masih kesulitan membuat keseimbangan, kesatuan, irama, harmoni dan
repetisi.Ada faktor yang mempengaruhi siswa dalam menggambar termasuk kurangnya motivasi siswa dalam belajar, baik motivasi dari eksternal maupun internal.Berdasarkan kondisi di lapangan sebagian besar siswa kurang mampu menggambar dengan baik, masih belum sesuai dengan prosedur dalam menggambar.hal ini juga didukung oleh, hasil belajar menggambar siswa masih kurang, siswa masih kesulitan dalam menggambar Ragam Hias. Oleh sebab itu peneliti tertarik menganalisis hasil gambar Ragam Hias siswa, dengan judul penelitian" Analisis Hasil Menggambar Ragam Hias Melayu Ditinjau Dari Prinsip-Prinsip Seni Rupa Karya Siswa Kelas VII SMP Kartika I-1 Medan Petisah 2018/2019”.

\section{KAJIAN TEORI}

\section{Analisis}

Adapun yang dimaksud dengan pengertian analisis menurut, Sugiyono (2008:335) mengatakan bahwa: "Analisis adalah proses mencari dan menyusun secara sistematis data yang diperoleh dari hasil wawancara, catatan lapangan, dan dokumentasi, dengan cara mengorganisasikan data ke dalam kategori, menjabarkan ke dalam unit-unit, melakukan sintesa, menyusun ke dalam pola, memilih mana yang terpenting dan yang penting dan yang akan dipelajari dan membuat kesimpulan sehingga mudah dipahami diri sendiri maupun orang lain”.

Selanjutnya sejalan dengan Naibaho (1998:9) mengatakan bahwa: "Analisis berarti kemampuan menguraikan atau menjabarkan sesuatu ke dalam bagian sehingga hasilnya dapat dimengerti”. Jadi, dalam menganalisis penulis harus bisa menguraikan dengan jelas dari hasil data yang telah diperoleh.

Maka berdasarkan pendapat di atas dapat diambil kesimpulan bahwa pengertian analisis adalah suatu aktivitas yang dilakukan melalui proses mencari dan menjabarkan suatu peristiwa mengumpulkan data secara sistematis sehingga seluruh data dapat disimpulkan kebenarannya secara keseluruhan.

\section{Menggambar}

Banyak pendapat yang ditulis dalam sebuah buku yang menjelaskan pengertian menggambar salah satunya menurut Sugiyanto, dkk (2014:4) dalam buku "Seni Budaya" mengatakan "Menggambar merupakan kegiatan manusia yang melibatkan koordinasi antara penglihatan dan gerakan halus tangan". Dalam menggambar dibutuhkan penglihatan yang teliti dan cermat.Gerakan dalam menggambar hendaknya halus dan penuh perasaan.Kegiatan menggambar menuntut objektivitas, artinya sesuai dengan objek yang 
digambar baik bentuk maupun warnanya.Gambar merupakan bahasa yang Universal dan telah berkembang sebelum dikemukakannya bahasa tulisan.Sejak zaman prasejarah manusia primitif telah mengenal gambar sebagai bahasa rupa.Hal ini dibuktikan dengan banyak ditemukannya gambar dan lukisan di goa-goa tempat manusia tinggal saat itu.

Menggambar bentuk berarti meniru objek, Menurut Suhernawan dan Nugraha (2010:88) bahwa: "Menggambar bentuk adalah menggambar dengan meniru objek gambar nyata yang ada di alam atau benda buatan. Bentuk benda dapat dibedakan menjadi dua, yaitu geometris dan nongeometris".

Gambar Ekspresif berawal dari imajinasi setiap masing-masing orang dengan tarikan garis secara spontan. Selanjutnya, Suhernawan dan Nugraha (2010:88) mengatakan bahwa: "Gambar ekspresif adalah gambar yang dibuat secara bebas berdasarkan pada imajinasi dan penafsiran penggambar pada objek".

Selanjutnya, Suhernawan dan Nugraha (2010:88) bahwa: "Gambar dekoratif adalah gambar yang berpedoman pada pola-pola atau motif tertentu...yang digambar secara berulang-ulang. Konsep utama dari gambar ini adalah menghias". Jadi, sehubungan dengn pengertian tersebut bahwa, gambar dekoratif lebih diutamakan untuk menghias.

Selanjutnya menurut Suhernawan dan Nugraha (2010:88) mengatakan bahwa: "Gambar konstruktif adalah gambar yang dibuat dengan mengikuti aturanaturan tertentu secara objektif. Aturan tersebut antara lain ukuran, skala, volume, bayangan dan proporsi“.

\section{Ragam Hias}

Kata Ornamen sudah tidak asing didengar, banyak pendapat para pakar mengenai Ornamen, salah satunya Menurut Sunaryo (2009:3) dalam buku "Ornamen Nusantara, Kajian Khusus Tentang Ornamen Indonesia" mengatakan bahwa "Kata ornamen berasal dari bahasa Latin ornare, berdasarkan arti kata tersebut berarti menghiasi”.

Selanjutnya pengertian Ornamen menurut Sustia (2018:24) dalam jurnal yang berjudul "Analisis Kesulitan Belajar Siswa Dalam Menerapkan Ornamen Batak Karo Pada Mata Pelajaran Taspestri di SMK Negeri 1 Berastagi" mengatakan bahwa : "Ornamen merupakan suatu seni hias yang paling dekat dengan kriya apalagi jika dikaitkan dengan hasil produknya. Pada perkembangan Ornamen, lebih lanjut pemanfaatan Ornamen di samping memiliki maksud- maksud tertentu, dan pada waktu kekinian (sekarang) banyak penekannya hanya sebagai penghias saja, dengan demikian Ornamen merupakan komponen seni yang ditambahkan atau sengaja dibuat dengan tujuan sebagai hiasan semata".

Berdasarkan pengertian di atas dapat disimpulkan bahwa Ornamen adalah bentuk gambar pola yang digunakan sebagai hiasan untuk memperindah suatu bidang atau benda.

Kehadiran sebuah Ornamen tidak semata sebagai pengisi bagian kosong dan tanpa arti, lebih-lebih karya Ornamen masa lalu. Bermacam bentuk Ornamen sesungguhnya memiliki beberapa fungsi, yaitu:

(1) Fungsi Murni Estetis, (2)Fungsi Simbolis

(3) Fungsi Teknis Konstruktif

\section{Sejarah Melayu}

Melayu termasuk salah satu suku yang ada di Indonesia terkhusus di Sumatera Utara. Istilah Melayu cukup beragam, Sehingga pengertian Melayu dalam Kamus Bahasa Indonesia (2003:278) bahwa: “Melayu adalah bangsa dan bahasanya". Dari pengertian tersebut bahwa Melayu termasuk suku bangsa di Indonesia yang memilki bahasa khas Melayu. Melayu adalah negeri yang mula-mula di diami.

Selanjutnya, arti kata Melayu menurut Adenansyah dalam Azmi (2012:6) adalah berasal dari kata "Melieau $=$ me-liau $=$ me-lie-au $=$ me-lie-au menjadi Melayu, yang artinya agung dan kebangaan. Jadi masyarakat Melayu sesungguhnya dapat menjadi suatu suku bangsa yang tinggi derajatnya, terutama bila dilihat dari hasil karya kebudayaannya".

Pengertian Melayu menurut pengertian suku bangsa lebih berdasarkan pada etnis. Walaupun begitu syarat bangsa Melayu masih diperlukan. Orang-orang Melayu biasanya mendiami kawasan Pesisir Sumatera Utara Kabupaten Langkat, Kotamadya Tanjung Balai, Medan Kabupaten Deli Serdang, Palembang, dan Riau.

Ragam Hias Melayu biasanya ditemukan pada rumahrumah panggung Melayu. Pada umumnya hiasan Ragam Hias berupa ukiran terdapat setiap ventilasi, tangga, pintu, jendela dan pinggir atap rumah. Menurut Lah Husny dalam Azmi (2012:88) mengatakan bahwa :“...ukiran atau gambar-gambar pada zaman primitif Melayu merupakan lukisan. Segala yang dilukiskan itu mempunyai arti dan hubungan dengan kekuatan gaib atau batin. Karena 


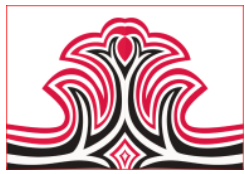

kemajuan zaman maka...keadirannya kehadirannya dianggap sebagai hiasan saja".

Selanjutnya menurut Sirait, dkk (1984:182) mengatakan: "Jenis Ragam Hias yang terdapat pada rumah tradisional terdapat beberapa bagian antara lain: Ornamen pada lubang hawa, terali, singab, lubang hawa bagian dalam, tudung angin”.

Berikut ini penjelasan tentang beberapa jenis-jenis Ragam Hias Melayu :

\section{Plana Kuda Kencana}

Posisi Plana Kuda Kencana biasanya terletak pada atap rumah bagian luar yang berbentuk segitiga. Sirait, dkk (1984:187) mengatakan “...ornamen tumbuhtumbuhan..terletak pada Singab bagian luar rumah Melayu pesisir pada komplek Medan Fair di Medan”.

Jala-Jala

Motif jala-jala sangat sederhana, biasanya terletak pada ventilasi udara pada jendela rumah. Seperti yang diungkapkan oleh Azmi (2012:143) bahwa: “...JalaJala dibuat atau diukir dengan posisi atap tepat di lubang hawa (ventilasi udara) dan singap".

\section{Tampuk Pinang}

Tampuk pinang terdapat pada sekitar atas atap, bentuk motif tampuk pinang seperti bunga. Azmi (2012:144) mengatakan "Tampuk Pinang menyiaratkan adanya penyelarasan hubungan kekerabatan agar seimbang dan harmonis serta rukun selalu sampai akhir khayat".

\section{Roda Sula}

Roda Sula penempatannya pada posisi atap lubang ventilasi. Sirait, dkk (1984:185) mengatakan: “Ornamen Roda Sula menggambarkan ...tujuh mata sula sebagai jari-jari rodanya. Mata sula melambangkan kekuatan dan ketahanan"

\section{Genting Tak Putus}

Genting Tak Putus berupa motif tumbuhan dan hewan berupa burung. Azmi (2012:144) mengatakan: "Penempatannya di atap lubang hawa (bagian dalam), maknanya rezeki yang mengalir terus tanpa henti”.

\section{Bunga Matahari}

Motif bunga matahari berbentuk seperti bunga matahari tersusun memanjang, motif bunga matahari posisi penempatannya di dinding rumah atau lubang angin.

\section{Pucuk Rebung}

Pucuk rebung di tempatkan pada sisi pinggir atap bagian bawah. Pucuk rebung melambangkan
Gorga Jurnal Seni Rupa

Volume 08 Nomor 02 Juli-Desember 2019 p-ISSN: 2301-5942 | e-ISSN: 2580-2380

keserasian dan kedamaian dalam rumah tangga. Saat ini bentuk pucuk rebung sudah banyak divariasikan sebagai hiasan di pinggir bawah atap rumah.

\section{Semut Beriring}

Semut beriring penempatannya di posisi pada dinding rumah. Azmi (2012:145) mengatakan bahwa: "Semut beiring...maknanya sipemilik rumah bersifat penolong antar sesama anggota keluarga".

Lebah Bergantung

Lebah bergantung biasanya di letakkan pada posisi atap bagian bawah. Azmi (2012:145) mengatakan "Lebah bergantung...artinya sipemilik rumah memperoleh keturunan yang banyak, menuju kebahagiaan berkerabat. selalu berpegang kepada iman dan taqwa".

\section{Roda Bunga}

Ragam Hias roda bunga berasal dari bentuk bungabunga, yang dimaksud hanya sebagai keindahan. Ragam Hias ini terdapat pada lubang hawa atau ventilasi rumah. Azmi (2012:144) mengatakan "Penempatanya di atap lubang hawa, maknanya keindahan dan ketentraman siempunya rumah “.

Menggambar Ragam Hias tidak hanya membutuhkan keahlian dan keterampilan, tetapi juga pengetahuan tentang Ragam Hias juga berpengaruh terhadap gambar yang dihasilkan. Begitu pula dengan media yang akan digunakan juga tak kalah penting, karena tanpa media tidak akan bisa terlaksana dalam proses menggambar.

Menggambar ragam hias dilakukan dengan dua teknik yaitu teknik mistar dan teknik manual. Teknik mistar dilakukan dengan alat bantu mistar atau jangka. Sedangkan, teknik manual dilakukan dengan beberapa teknik, antara lain, teknik linear, teknik arsir, plakat dan teknik akuarel.

Teknik menggambar Ragam Hias terbagi menjadi dua sebagai berikut :

a) Teknik Mistar, b) Teknik Manual.

\section{METODE PENELITIAN}

Teknik pengumpulan data yang digunakan adalah observasi, dan dukomentasi. Metode yang digunakan dalam penelitian ini adalah metode deskriptif. Instrument penelitian yang digunakan yaitu lembar penilaian dan alat berupa kamera.Teknik analisis data yang digunakan dalam penelitian ini adalah teknik analisis data deskriptif kualitatif, yaitu mendeskripsikan atau bentuk dari gambaran yang sejelas-jelasnya mengenai objek yang diteliti dan 


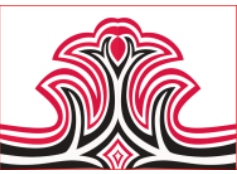

menilai beberapa besar kemampuan siswa dalam menerapkan prinsip seni rupa dalam menggambar ragam hias.

\section{HASIL DAN PEMBAHASAN \\ 1.Hasil}

1). Karya 1

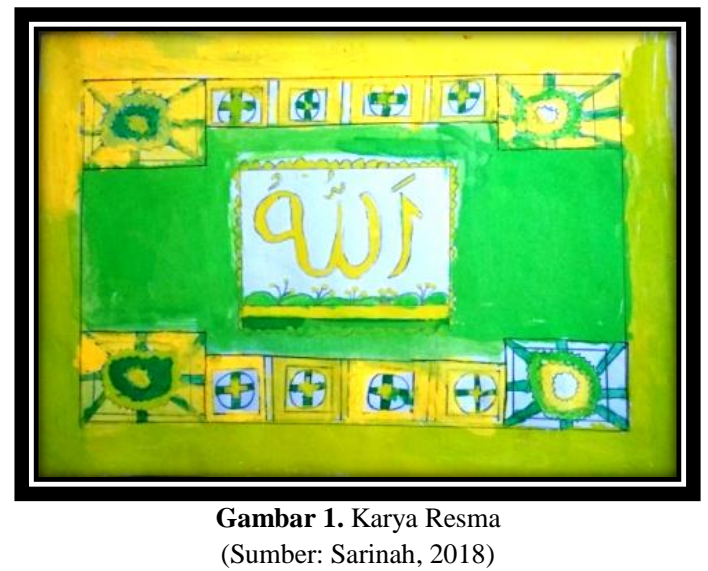

Berdasarkan tinjauan prinsip seni rupa, secara keseluruhan karya Resma dikategorikan cukup bagus dengan total nilai $=385$ dan nilai rata-rata $(\mathrm{r})=$ 77.Prinsip keseimbangan memperoleh nilai $=78$ dengan kategori C (Cukup). Prinsip keseimbangan yaitu karya tersebut, keseimbangan dalam dalam menata bentuk Ragam Hias dengan bidang kertas terlihat berat sebelah, bidang kanan dan kiri tidak dibuat motif sehingga terlihat kosong. Pola Ragam Hias dengan bidang kertas sudah cukup, ada penambahan center point dengan tulisan kaligrafi.

Prinsip kesatuan memperoleh nilai $=78$ dengan kategori C (Cukup) dengan prinsip kesatuan yaitu kesatuan antara Ragam Hias dengan bidang kertas belum tertata dengan rapi sehingga kesatuan tersebut belum telihat jelas. Dalam pemilihan warna sudah cukup bagus memilih warna sesuai dengan Ragam Hias Melayu .

Prinsip irama memperoleh nilai $=75$ dengan kategori C (Cukup), prinsip irama yaitu karya tersebut melakukan pengulangan pola Ragam Hias, tidak ada muncul irama garis, jaraknya terlalu dekat antara satu dan lain, belum muncul kesan variasi bentuk dan warna, bentuk pada gambar tersebut hanya menerapkan dua motif sehingga tidak banyak variasi, begitu juga dengan warna hanya hijau dan kuning tidak ada variasi penambahan warna.

Prinsip harmoni memperoleh nilai $=78$ dengan kategori C (Cukup) keselarasan yaitu karya tersebut
Gorga Jurnal Seni Rupa

Volume 08 Nomor 02 Juli-Desember 2019 p-ISSN: 2301-5942 | e-ISSN: 2580-2380

belum muncul keselarasan unsur seni rupa dengan pola motif, pada keselarasan motif belum terlihat jelas.

Prinsip repitisi memperoleh nilai $=76$ dengan kategori C (Cukup) dengan prinsip repitisi yaitu kebersihan dalm membuat motif masih kurang, kesamaan dalam pengulangan bentuk Raham Hias belum muncul dan kerapian dalam pengulangan motif masih kurang, dalam gambar tersebut pengulangan bentuk yang diterapkan pada gambar tersebut masih biasa tidak terlalu detail sehingga hanya terkesan biasa.

\section{2).Karya 2}

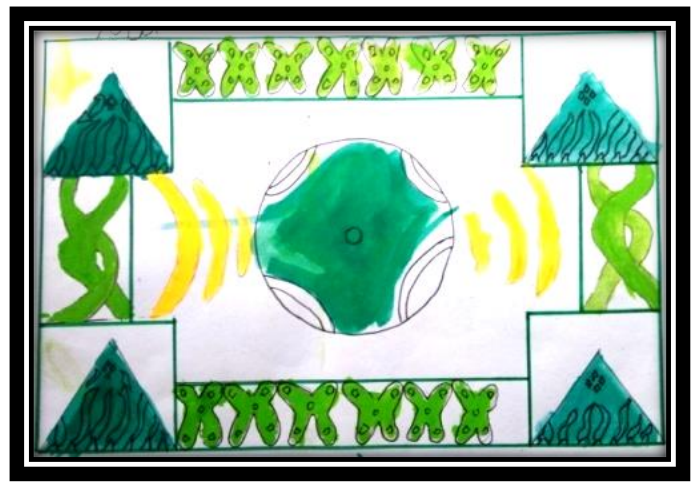

Gambar 2. Karya Yuda

(Sumber: Sarinah, 2018)

Berdasarkan tinjauan prinsip seni rupa, secara keseluruhan karya Yuda dikategorikan cukup bagus dengan total nilai $=365$ dan nilai rata-rata $(\mathrm{r})=$ 73.Pada prinsip keseimbangan memperoleh nilai $=73$ dengan kategori C (Cukup). keseimbangan dalam dalam menata bentuk Ragam Hias dengan bidang kertas tidak terlihat berat sebelah, bidang kanan dan kiri dibuat motif tambahan sehingga tidak terlihat kosong. Pola Ragam Hias dengan bidang kertas sudah cukup, ada penambahan lingkaran center point tetapi tidak ada tulisan atau pun hiasan motif didalamnya.

prinsip kesatuan memperoleh nilai $=72$ dengan kategori C (Cukup), dengan prinsip kesatuan yaitu kesatuan antara Ragam Hias dengan bidang kertas belum tertata dengan rapi. Dalam pemilihan warna sudah cukup bagus, sesuai dengan Ragam Hias Melayu.

Prinsip irama memperoleh nilai $=74$ dengan kategori C (Cukup), prinsip irama yaitu karya tersebut melakukan pengulangan pola Ragam Hias, tidak ada muncul irama garis, jaraknya tidak terlalu dekat antara satu dan lain, belum muncul kesan variasi bentuk dan warna. 
Prinsip harmoni memperoleh nilai $=72$ dengan kategori C (Cukup) dengan deskripsi pada keselarasan yaitu karya tersebut belum muncul keselarasan unsur seni rupa dengan pola motif.

Prinsip repitisi memperoleh nilai $=74$ dengan kategori C (Cukup), dengan prinsip repitisi yaitu kebersihan dalm membuat motif masih kurang, kesamaan pengulangan bentuk Raham Hias belum muncul dan kerapian dalam pengulangan motif masih kurang.

\section{Pembahasan}

Pembahasan dari hasil karya di atas dapat disimpulkan bahwa berdasarkan penilaian kelima prinsip seni rupa pada karya pertama, maka rata-rata nilai yang didapat 78 pada prinsip keseimbangan, kesatuan dan harmoni, nilai terendah yang diperoleh yaitu 75 dengan kategori cukup, terletak pada aspek penilaian irama.

Selanjutnya, berdasarkan penilaian kelima prinsip seni rupa pada karya kedua prinsip irama dan repetisi pada prinsip irama dan repetisi memperoleh nilai 74 , nilai terendah yang diperoleh yaitu 72 dengan kategori cukup, terletak pada aspek penilaian kesatuan dan harmoni.

\section{KESIMPULAN DAN SARAN}

\section{Kesimpulan}

Berdasarkan hasil penelitian data di atas maka dapat disimpulkan bahwa, secara keseluruhan hasil karya gambar Ragam Hias Melayu siswa SMP Kartika I-1 Medan Petisah Berada dalam kategori cukup dengan nilai rata-rata 75 secara keseluruhan adalah Adapun kesimpulan-kesimpulan berdasarkan prinsip-prinsip seni rupa yaitu sebagai berikut:

\section{1).Keseimbangan}

Keseimbangan yang di terapkan pada bidang kertas tidak terdapat penataan yang berlebihan. Secara keseluruhan karya hasil menggambar Ragam Hias Melayu di SMP Kartika I-1 Medan Petisah pada aspek keseimbangan memperoleh nilai 75 dengan kategori cukup bagus.

\section{2).Kesatuan}

Kesatuan yang muncul pada hasil karya menggambar Ragam Hias Melayu, terdapat Ragam Hias yang masih belum terlihat bersatu dalam penerapan bentuk dengan pola Ragam Hias. Secara keseluruhan karya hasil menggambar Ragam Hias Melayu di SMP Kartika I-1 Medan Petisah pada aspek kesatuan memperoleh nilai 75 dengan kategori cukup bagus.

\section{3).Irama}

Irama yang dimunculkan pada hasil karya terdapat Pemilihan warna sesuai dengan Ragam Hias Melayu, irama dalam variasi bentuk, warna dan irama garis belum terlihat. Secara keseluruhan karya hasil menggambar Ragam Hias Melayu di SMP Kartika I-1 Medan Petisah pada aspek irama memperoleh nilai 74 dengan kategori cukup bagus.

\section{4).Harmoni}

Harmoni yang muncul pada hasil karya menggambar Ragam Hias Melayu, terdapat keselarasan Ragam Hias yang cukup terlihat keselarasan antara bentuk Ragam Hias yang satu dan yang lain. Secara keseluruhan karya hasil menggambar Ragam Hias Melayu di SMP Kartika I-1 Medan Petisah pada aspek keseimbangan memperoleh nilai 75 dengan kategori cukup bagus.

\section{5).Repetisi}

Repetisi yang dimunculkan pada hasil karya menggambar Ragam Hias Melayu, terdapat pengulangan bentuk Ragam Hias yang belum cukup terlihat rapi dalam membuat bentuk Ragam Hias. Secara keseluruhan karya hasil menggambar Ragam Hias Melayu di SMP Kartika I-1 Medan Petisah pada aspek keseimbangan memperoleh nilai 75 dengan kategori cukup bagus.

\section{Saran}

Disarankan kepada siswa dalam menggambar Ragam Hias, lebih dahulu mengamati bentuk dan jenis Ragam Hias sebelum membuat sketsa.

Disarankan siswa mampu membuat variasi warna seperti, hijau tua, hijau muda, kuning tua dan kuning muda.

Disarankan siswa mampu membuat variasi pengulangan bentuk yaitu ada bentuk kecil, sedang dan besar.

Disarankan kepada guru mampu mempraktikkan tahapan menggambar Ragam Hias.

\section{DAFTAR RUJUKAN}

Azmi, (2012). Rumah Panggung Melayu Deli. Medan.UNIMED Press.

Naibaho, Togarma dan Wegig Murwonugroho. (1998). Metodologi Riset Seni Rupa dan Desain. Jakarta: Universitas Trisakti.

Sirait, Baginda. (1980). Pengumpulan dan Dokumentasi Ornamen Tradisional di Sumatera Utara. Sumatera Utara. 
Sugiyanto, (2014). Seni Budaya. Jakarta:PT Gelora Aksara Pratama.

Sugiyono, (2008). Metode Penelitian, Kualitatif $R \& D$

Bandung: Alfabeta.

Suhernawan, Rachmat dan Rizal Ardhya Nugraha.

(2010). Seni Rupa SMP/MTS Kelas VII, VII

dan IX. Jakarta: Pusat Perbukuan Kementrian.

Sunaryo, Aryo. (2009). Ornamen Nusantara Kajian Khusus Ornamen Indonesia.Semarang: Dahara Prize.

Sustia, Linda dan Juliarti. (2014).Analisis Kesulitan Belajar Siswa Dalam Menerapkan Ornamen Batak Karo Pada Mata Pelajaran Taspestri Di SMK Negeri 1 Berastagi.Jurnal Pendidikan Tata Busana,(1) 24. 